\title{
Vertebrate diversity in a thirty year old analogue forest in Pitigala, Elpitiya, in the Galle District of Southern Sri Lanka
}

\author{
S. N. Gamage, W. K. D. D. Liyanage, A. Gunawardena \\ Department of Animal Science, Faculty of Agriculture, University of Ruhuna, Kamburupitiya, Matara, Sri \\ Lanka. asokag2006@yahoo.com \\ S. Wimalasuriya \\ Land Owners Restore Rainforest In Sri Lanka, Bangamukanda Estate, Pitigala, Galle, Sri Lanka.
}

\begin{abstract}
Most of the natural ecosystems in the wet zone are severely fragmented and interspersed between human managed agro ecosystems and home gardens. There is growing evidence that traditional agro-ecosystems contribute to sustain the regional biodiversity of many invertebrate and vertebrate species. Analogue forest as a concept is accepted by agronomists and conservationists, which would bring profits in the long-term sustainable basis. The Bangamukanda Estate is an example of a 18 hectares plantation (tea, rubber and cinnamon) that has been converted into an analogue forest. Objective of the study was to assess the current vertebrate diversity in this 30 -year-old analogue forest. Total of 206 species of vertebrates belonging to 74 families were observed during the study period, out of that 58 species were endemic to Sri Lanka. The findings of the survey clearly highlighted the contribution of analogue forest systems towards sustaining a rich biodiversity. In addition analogue forest systems can be used to link the forest patches in the wet zone.
\end{abstract}

Key words: Vertebrate diversity, Analogue forest, Conservation

\section{Introduction}

Since sounding the alarm of the biodiversity crisis in the 1970s, most conservationists have focused on establishing protected areas to conserve endangered habitats and species (Scherr \& Shames 2006). Agricultural production areas have been seen as useless for conservation activities and their growth viewed as a threat (Scherr \& Shames 2006).

In recent decades, sustainable farmers and researchers around the world have responded to the extractive industrial model with ecology based approaches such as eco-agriculture, agro-forestry or analogue forest (Earles 2005, Scherr \& Shames 2006). All of them, representing thousands of farms, have contributed to our understanding of what sustainable systems are, and each of them shares a vision of "farming with nature", an agro-ecology that promotes biodiversity, recycles plant nutrients, protects soil from erosion, conserves and protect water. Also uncultivated portions of mainly agricultural landscapes can provide patches of habitat for forest wildlife and form corridors that connect protected areas and allow species to 
continue genetic contact with populations that would otherwise be isolated (Scherr \& Shames 2006). For example, millions of hectares of multi-strata 'agro-forests' in Indonesia produce commercial rubber, fruits, spices and timber. The number of wild plant and animal species in these agro-forests is often nearly as high as in natural forests (Scherr \& Shames 2006). There is growing evidence that traditional agroecosystems contribute to sustain the regional biodiversity of many invertebrate and vertebrate species (Lawler, 2001).

Vast extents of Sri Lanka's biodiversity rich lands which were transferred into mono crop plantations during the colonial era are regenerating in many places due to various reasons, both natural and man made. The Bangamukanda Estate is an example which consists of 18 hectares plantation land (tea, rubber and cinnamon) that has been deliberately converted to an analogue forest as a direct result of the far sighted, land use policy of the 1970 -1977 government which introduced crop diversification of uneconomic tea lands. The Bangamukande Estate is situated in Pitigala, Galle, Sri Lanka. The land was transformed into an undulating terrain that consists of a series of ridges and valleys with an altitudinal range from $100 \mathrm{~m}$ to $300 \mathrm{~m}$. It has an intricate network of small streams, which drains into the river Benthara.

In 1904 ancestors of the present owner planted agricultural mono crops such as cinnamon, rubber, and tea . This practice continued up to 1973. It was changed in 1973 and 12 hectares of cinnamon and tea land were transferred into analogue forest using a government subsidy, under crop diversification of uneconomic tea lands. The remaining rubber field of 6 hectares is presently allowed to regenerate into forestland while being tapped.

Sri Lanka's point of view is that, the primary natural ecosystems found in the low country wet zone consist of lowland rainforests, which are severely fragmented and interspersed between human managed agro ecosystems and home gardens. These wet-zone ecosystems harbour a high percentage of endemic and globally threatened species of animals and plants (Gunatilleke et al., 2005; Pethiyagoda, 2005). Wetzone of Sri Lanka along with the Western Ghats is recognized as one of the world's 11 biodiversity "hyperhot" hotspots, which demand extensive conservation investment (Myers et al. 2000, Brookes et al. 2002). However agro ecosystems and human settlements cover most of the land area in the wet-zone of Sri Lanka (Gamage 2005). These habitats are frequently subjected to human modification and therefore the environment of these habitats is constantly changing whose impact on the biodiversity is little known. However, these man made habitats function as an integral part of the habitats of large number of fauna and flora but most of the studies are presently confined to herpetofauna and freshwater fish (Gamage 2000, Gamage et al. 2002, Gamage et al. 2005).

Analogue forest is a tree-dominated ecosystem that is analogous in structure and function to the original climax and sub-climax forest community. With time, the natural succession of any undisturbed forest community is to increase in diversity and stability until a highly complex ecosystem or Climax State is reached. When an ecosystem is designed to mimic the indigenous Climax State, the efficiency and 
dynamics of the natural processes can be replicated. Such forests are referred to as analogue forests which are considered to provide economic benefits. A wide range of supplies can be produced that may include: fruit, nuts, herbs, cut flowers and cut-foliage, pharmaceuticals, and timber. Furthermore this type of concept can be used to link the fragmented forest patches in the wet zone of Sri Lanka.

Therefore the main objective of this study was to assess the diversity of vertebrate fauna in this 30 years old analogue forest (Bangamukanda Estate).

\section{Materials and Methods}

The Bangamukande Estate is situated in Niyagama Divisional Secretate Area in Galle District of Southern Province of Sri Lanka, at $06^{0} 20^{\prime} 46$ " N - 080 16' 26" $\mathrm{E}$, average annual rainfall $2300 \mathrm{~mm}$, average temperature $28^{\circ}$, and humidity $90 \%$. Approximate distances from BKE to the larger forest complexes are as follows:

South - $4 \mathrm{~km}$ to Polgahakande-Malabure forest reserve

East - $1 \mathrm{~km}$ to Hiniduma forest reserve

Southwest - $8 \mathrm{~km}$ to Beraliya forest reserve

Southeast - $100 \mathrm{~m}$ to Bangamukanda proposed forest

Southeast - $8 \mathrm{~km}$ to Kannaliya-Dediyagala-Nakiyadeniya forest reserve

Northeast - $12.5 \mathrm{~km}$ to Sinharaja forest reserve World Heritage site

North $\quad-\quad 11 \mathrm{~km}$ to Kalugalkande Forest Hermitage and reserve

Different methods were used to assess the vertebrate fauna in the Bangamukanda Estate. The study was carried out during August 2003 to November 2005.

\subsection{Herpetofauna}

The quadrate sampling method was the main method used to study the herpetofauna. It involves placing small squares (quadrates) at randomly selected sites within a habitat and thoroughly searching these squares for presence of herpetofauna (Heinen 1992). Quadrate sampling was done during September 2003 to November 2003. A total of eighteen $8 \times 8 \mathrm{~m}$ quadrates were placed at randomly selected points in each study site. In placing of quadrates, areas with a high relief angle or areas adjacent to tree-fall gaps were omitted. All of the sampled quadrates in the agroecosystems were located within $1-2 \mathrm{~km}$ from natural vegetations. A $45 \mathrm{~cm}$ height polythene fence was placed along the sides of the quadrate to prevent animals from escaping. A minimum of two people was engaged in all of the sampling sessions. Sampling involved sorting through all leaf litter in the plot, tree trunks, branches, under stones and logs (Fauth et al. 1989, Heinen 1992). Furthermore fixed line traces were also used to assess the herpetofauna.

\subsection{Avifauna and Mammals}

Fixed line transect method was used to assess avian and mammalian richness of the study site (Sutherland 1996). Day and night surveys were carried out during a period from August 2003 to November 2005. Field observations were made from 6.30 am to $9.00 \mathrm{am}$ and $4.00 \mathrm{pm}$ to $6.00 \mathrm{pm}$. In addition night observations were made from $7.00 \mathrm{pm}$ to $10.00 \mathrm{pm}$ and $2.00 \mathrm{am}$ to $6.00 \mathrm{am}$. 
Gamage et al.,: Vertebrate diversity in a thirty year...

Table 1 The number of vertebrate species, families and endemic species recorded in each taxonomic group during the study period.

\begin{tabular}{|l|l|l|l|l|}
\hline Vertebrate group & $\begin{array}{l}\text { Number of } \\
\text { species }\end{array}$ & $\begin{array}{l}\text { Number of } \\
\text { Families }\end{array}$ & $\begin{array}{l}\text { Number of } \\
\text { Endemic } \\
\text { species }\end{array}$ & $\begin{array}{l}\text { Total number } \\
\text { of endemic } \\
\text { species } \\
\text { recorded in } \\
\text { Sri Lanka }\end{array}$ \\
\hline Amphibians & 18 & 3 & 12 & 79 \\
Snakes & 25 & 5 & 9 & 46 \\
Tetra pods reptiles & 17 & 5 & 8 & 48 \\
Fish & 23 & 9 & 13 & 44 \\
Birds & 89 & 34 & 10 & 25 \\
Mammals & 34 & 18 & 6 & 16 \\
Total & 206 & 74 & 58 & 258 \\
\hline
\end{tabular}

\subsection{Identification}

The different groups of vertebrates were identified using the most recent taxonomic keys and guides available for the respective taxonomic group (Freshwater fish: Pethiyagoda (1991), Deraniyagala (1949); Amphibians: Dutta \& ManamendraAarachchi (1996), Manamendra-Arachchi \& Pethiyagoda (1998), ManamendraArachchi \& Pethiyagoda (2005), Meegaskumbura \& Manamendra-Arachchi (2005); Serpentoid reptiles: De Silva (1990), Pethiyagoda \& Manamendra-Arachchi, (1998), Das \& De Silva (2005); Birds: Henry (1971), Kotagama \& Fernando (1992); Mammals: Phillips (1981), Corbet \& Hill (1992), Groves (2001). Bambaradeniya eds. (2006) was used for the confirmation of nomenclature.)

\section{Results}

In the course of this study 206 species of vertebrates belonging to 74 families were observed out of which 58 species were endemic to Sri Lanka (Table 1). The vertebrate fauna was comprised 18 species of amphibians, 25 species of snakes, 17 species of tetrapod, reptiles, 23 species of fish, 89 species of birds and 34 species of mammals (Table 01 \& Appendix). A total of 54 endemic vertebrate species were recorded during the survey which include 12 amphibians and 13 fresh water fish.

Table 2 shows the conservation status of some threatened species found in the study site of which four were vulnerable, six were endangered, one critically endangered and one was data deficient. This critically endangered frog (Philatus nemus) is a newly discovered species which was only found in Hiniduma Kanda forest reserve previously (Manamendra-Arachchi \& Pethiyagoda, 2005).

\section{Discussion}

The results indicate that the Bangamukanda Estate (analogue forest) is an agroecosystem that sustains a high diversity of vertebrate fauna. A variety of methods targeting at different groups enabled the documentation of vertebrate diversity in Bangamukanda Estate expressed in terms of species richness.

The total vertebrate richness shows that Bangamukanda Estate harbours a comparatively high number of species. In addition to the species richness, the study 
Table 2 Conservation status of some threatened species, recorded in Bangamukanda Estate.

\begin{tabular}{|l|l|}
\hline Species & Conservation status \\
\hline Rana aurantiaca & Vulnerable (Vu) \\
Nanophrys ceylonensis & Vulnerable (Vu) \\
Polipedates longinasus & Endangered (En) \\
Polypedates eques & Endangered (En) \\
Philatus nemus & Critically Endangered (Cr) \\
Philatus folicola & Endangered (En) \\
Lepidocephalichthys jonklaasi & Endangered (En) \\
Sicyopus jonkalaasi & Data deficient (Dd) \\
Centropus chlorohyncho & Vulnerable (Vu) \\
Loris tardigradus tardigradus & Endangered (En) \\
Trachypithecus vetullus vetullus & Endangered (En) \\
Macaca sinica aurifrons & Vulnerable (Vu) \\
\hline
\end{tabular}

site is also evident for providing niches for a large number of endemic vertebrates. The results clearly indicate that such agro-forestry systems are closer to natural conditions and maintain high biodiversity. The study site is providing niches for nine globally threatened species of which one species is critically endangered. This clearly shows the importance of this ecosystem.

Most of the birds and mammal species are using this estate as a temporary refuge ground or feeding area, while they move from one forest patch to another suggesting that further studies are necessary to evaluate the importance of agricultural systems as means of connecting forest patches in the country.

\section{Conclusion}

According to the results, it can be concluded that analogue forest systems are sustaining high level of vertebrate diversity and endemism. As a concept analogue forestry system is biodynamic and environmentally friendly (Hochegger 1998; Earles 2005). Our study confirmed this concept. In addition the findings of the survey clearly highlighted the contribution of analogue forest systems towards sustaining rich biodiversity. Such agro-ecosystems can be used to link the forest patches in the wet zone. However, a detailed study on analogue forest systems has to be carried out for further confirmation of the validity of the concept and to plan conservation strategies to increase biodiversity in the agro ecosystems.

\section{References}

Brookes, T.M., Mittermeier, R.A., Mittermeier, C.G., Fonseca, G.A.B.Da, Rylands, A.B., Konstant, W.R., Flick, P., Pilgrim, J., Oldfield, S., Magin, G. \& HiltonTaylor, C. (2002). Habitat loss and extinction in the hotspots of biodiversity. Conservation Biology. 16: 909-923.

Bambaradeniya, C.N.B. (Editor). (2006). Fauna of Sri Lanka: status of Taxonomy, Research \& Conservation. The World Conservation Union, Colombo, Sri Lanka \& Government of Sri Lanka. Viii + 308pp. 
Corbert, G.B. \& Hill, J.E. (1992). Mammals of the Indomalayan Region: A systematic Review. Oxford University, Oxford, UK.

Deraniyagala, P.E.P. (1949). Some vertebrate animals of Ceylon. National Museum Pictorial Series, 1: 1-41.

De Silva A. (1990). Colour Guide to the Snakes of Sri Lanka. $R$ \& $A$ Publishing Ltd., Avon, England, 130pp.

Dutta, S.K., \& Manamendra-Arachchi, K. (1996). The Amphibian fauna of Sri Lanka. Wildlife Heritage trust of Sri Lanka, Colombo, 280pp.

Earles, R. (2005). Sustainable Agriculture: An Introduction Publication of ATTRA, the National Sustainable Agriculture Information Service. USA.

Fauth, J.E., Crother, B.I. \& Slowinski, J.B. (1989). Elevational patterns of richness, evenness, and abundance of the Costa Rican leaf litter herpetofauna. Biotropica 21(2): 55-73.

Gamage, S.N. (2000). Fresh water fish diversity and habitat variations in streams under different vegetation in Hiniduma, Sri Lankain . BSc thesis. Faculty of Agriculture, University of Ruhuna. Kamburupitiya, Sri Lanka.

Gamage, S.N., Liyanage, W.K.D.D. \& Guanawardena, A. (2002). Comparison of fish diversity and the habitat structure of streams in rubber and oil-palm plantations in Nakiyadeniya Galle. Sri Lanka Association for the Advancement of Science, Annual Conference 2002, University of Colombo.

Gamage, S.N. (2005). A comparative study on Biodiversity of selected manmade and Natural habitats in low country wet zone of Sri Lanka. MPhil thesis. Faculty of Agriculture, University of Ruhuna. Kamburupitiya, Sri Lanka.

Groves, P.C. (2001). Primate Taxonomy. Smithsonian Institution Press, Washington D.C.

Gunatilleke, I.A.U.N., Gunatilleke, C.V.S. \& Dilhan, M.A.A.B. (2005). Plant biogeography and conservation of the southwestern hill forests of Sri Lanka. The Raffles Bulletin of Zoology, Supplement No. 12: 9-22

Henry, G.M. (1971) A guide to the Birds of Ceylon (Sri Lanka) with 30 half-tone plates of which 27 are coloured and 136 black and white drawings. (2nd edition). K.V.G. de Silva $\&$ Sons, Kandy, Ceylon (Sri Lanka). 457pp.

Heinen, J.H. (1992). Comparisons of the leaf litter herpetofauna in abundoned cacao plantaions and primary rain forest in Costa Rica: some implications for faunal restoration. Biotropica 24(3): 431-439.

Hochegger, K. (1998). Farming like the forest: traditional home garden systems in Sri Lanka. Tropical Agroecology 191, Margraf Verlag, Wikersheim, Germany, 203pp.

Kotagama, S.W. \& Fernando, P. (1992). A field guide to the birds of Sri Lanka. Wildlife Heritage Trust of Sri Lanka, Colombo 8, Srilanka. 226pp.

Lawler, S. P. (2001). Rice fields as temporary wetlands: A review. Israel J. of Zoology, 47 (3), 513-528. 
Manamendra-Arachchi, K., \& Pethiyagoda, R. (1998). A synopsis of Sri Lankan Bufonidae (Amphibia: Anura) with discription of new species. J. South Asian Nat. Hist., 3(1), 213-247.

Manamendra-Arachchi, K., \& Pethiyagoda, R. (2005). The Sri Lankan shrub-frogs of Genus Philautus Gistel., 1848 (Ranidae: Rhacophorinae), with discription of 27 new species. The Raffles Bulletin of Zoology, Supplement No. 12: 163-303.

Meegaskumbura, M., \& Manamendra-Arachchi, K. (2005). Description of eight new species of shrub frogs (Ranidae: Rhacophorinae: Philautus) From Sri Lanka. The Raffles Bulletin of Zoology, Supplement No. 12: 305-338

Myers, N., Mittermeier, R.A., Mittermeier, C.G., Fonseca, G.A.B.Da \& Kent, J. (2000). Biodiversity hot spots for Conservation Priorities. Nature. 403: 853-858.

Phillips, W.A.A. (1981). Manual of the Mamals of Sri Lanka. Wildlife and Nature Protection Society of Ceylon (Sri Lanka). Colombo. Vol. I, II, \& III.

Pethiyagoda, R. (1991). Freshwater fishes of Sri Lanka. Wildlife Heritage Trust, Colombo. xiv+362pp.

Pethiyagoda, R. (2005). Exploring Sri Lanka's Biodiversity. The Raffles Bulletin of Zoology, Supplement No. 12: 1-4

Pethiyagoda, R., \& Manamendra-Arachchi, K. (1998) Evaluating Sri Lanka's amphibian diversity. Occ. Pap. Wildlife Heritage Trust. 2:1-12.

Pethiyagoda, R. \& Kottelat, M. (2005). A review of the barbs of the Puntius filamentosus group (Teleostei: Cyprinidae) of southern India and Sri Lanka. In: Yeo, D.C.J.P.K.L. Ng \& R. Pethiyagoda (eds.), Contributions to biodiversity exploration and research in Sri Lanka. The Raffles Bulletin of Zoology, Supplement No. 12: $127-144$.

Scherr, S.J. \& Shames, S. (2006). Agriculture: a threat or promise for biodiversity conservation. Arborvitce The IUCN/WWF Forest Conservation Newsletter.

Sutherland, J.W. (1996) Ecological census techniques. Cambridge University Press. UK. 336pp.

\section{Acknowledgments}

We wish to acknowledge members of LORRIS and BEOG for invaluable assistance provided in the field. Very special thank to Mr. Dharma Sri Kandambii (Curator, National Maritime Museum, Galle) for providing advise and guidance in the taxonomic identification. Member's of the Galle Wild Life Conservation Society are greatly acknowledge for their great assistance in the taxonomic identification of fauna. Dr. K.A.I. Nekaris and Lilia Bernede provided necessary literature and equipment for the survey. We also thank NHK Japan and Nocturnal Primate Research Group (Oxford Brooks University) for providing some funds.

\section{Appendix}


LIST OF FRESHWATER FAUNA OBSERVED AT BKE.

\section{Family: Aplocheilidae}

\section{Sub Class: OSTEICHTHEYS}

1. *Aplocheilus werneri

Family: Anguillidae

2. Anguilla bicolour

Family: Bagridae

3. Mystus gulio

4. Mystus keletius

Family: Balitoridae

5. * Schistura notostigma

Family: Cobitidae

6. * Lepidocephalichthys jonklaasi

7. Lepidocephalichthys thermalis

Family: Cyprinidae

8. Danio malabaricus

9. *Esomus thermoicos

10. * Garra ceylonensis

11. Puntius amphibious

12. Puntius bimaculatus

13. *Puntius cumingii
Werner's killifish

Level finned eel

Long whiskered catfish

Yellow catfish

Banded mountain loach

Jonklas loach (En)

Common spiny loach

Giant danio

Flying barb

Stone sucker

Scarlet-banded barb

Redside barb

Cuming's barb

(Endemic - *)

LIST OF AMPHIBIAN SPECIES OBSERVED AT BKE.

\section{Order: APODA}

\section{Family: Ichthyophiidae}

1. *Ichthyophis glutinosus (Linnaeus 1758)

\section{Order: ANURA}

\section{Family: Bufonidae}

2. Bufo melanostictus Schneider 1799

3. * Bufo atukoralei Bogert \& Senanayaka 1966

Family: Ranidae

\section{Subfamily: Raninae}

4. Rana aurantiaca Boulenger 1904

5. Rana temporalis (Günther, 1864)

6. *Fejervarya (Limnonectes) kirtisinghei Manamendra-Arachchi \& Gabadage, 1994

7. Fejervarya (Limnonectes) limnocharis (Boie,1835)

8. Hoplobatrachus crassus (Jerdon 1853)
- Common yellow-band cecillian

- Common house toad

- Athukorala's dwarf toad

- Golden frog $(\mathrm{Vu}) /$ Small wood frog

- Bronzed frog / Common wood frog

- Kirtisinghe's frog

- Common paddy field frog

- Jerdon's bull frog 
9. * Nanophrys ceylonensis (Günther, 1864)

10. * Lankanectes corrugatus (Peter 1863)

11. Euphlyctis hexadactylus (Lesson, 1834)

12. Euphlyctis cyanophlyctis (Schneider, 1799)

Subfamily: Rhacophorinae

13. *Polypedates eques(Günther, 1858)

14. *Polypedates cruciger Blyth, 1852

15. *Polypedates longinasus (Ahl, 1931)

16. *Philautus abundus

Manamendra-Arachchi \& Pethiyagoda, 2005

17. *Philautus folicola

Manamendra-Arachchi \& Pethiyagoda, 2005

18. *Philautus. nemus

Manamendra-Arachchi \& Pethiyagoda, 2005
- Sri Lankan rock frog $(\mathrm{Vu})$

- Corrugated water frog

- Indian green frog / Sixtoe green frog

- Skipper frog

- Saddled tree frog (En)

- Common hourglass treefrog

- Long-snouted tree frog (En)/

Sharp snout saddle tree frog

- Labugama shrub frog

- Anthropogenic shrub frog (En)

- Southern shrub frog $(\mathrm{Cr})$

LIST OF REPTILE SPECIES OBSERVED AT BKE.

\section{Class-REPTILIYA}

Order: SERPENTES

Family: Boidae

1.

\section{Family: Elapidae}

2.

3.

Family: Colubridae

4.

5.

6.

7.

8.

9.

Python molurus (Linnaeus, 1758) - Rock Python / Indian python

Naja naja (Linnaeus, 1758) - Indian cobra

*Bungarus ceylonicus Günther, - Sri Lanka krait 1864

*Xenochrophis

(Boulenger,1891)

Xenochrophis piscator (Schneider, - Checkered keelback 1799)

*Balanophis ceylonensis (Günther, - Sri Lanka Blossom Krait / 1858)

*Aspidura guentheri Ferguson, - Gunther's Rough-side 1876

Amphiesma stolata (Linnaeus, - Buff strip keelback 1758)

Ahaetulla nasutus (Lacepede, - Green vine snake 1789) 
10.

11.

12.

13.

14.

15.

16.

17.

18.

19.

20.

21.

Boiga ceylonensis (Günther, 1858) - Sri Lanka Cat snake

Boiga forsteni (Dumeril, Bibron \& - Forten's Cat Snake Dumeril, 1854)

Chrysopelea ornate (Shaw, 1802) - Ornate Flying Snake

* Dendrelaphis bifernalis - Boulenger's bronze-back

(Boulenger, 1890)

Dendrelaphis tristis (Daudin, 1803) - Common bronze-back

Dryocalamus nympha (Daudin, - Common bridal snake 1803)

Elaphe helena (Daudin, 1803) - Trinket snake

Lycodon aulicus (Linnneaus, 1758) - Common wolf snake

*Lycodon striatus (Shaw, 1802) - Shaw's wolf snake

Coluber mucosus (Linnaeus, 1758) - Rat Snake

Oligodon arnensis (Shaw, 1802) - Common banded kukri snake

*Oligodon sublineatus

- Streaked kukri snake /

Dumeril's kukri snake

(Dumeril, Bibron \& Dumeril, 1854)

Family: Cylindrophiidae / Europeltidae

22 .

Family: Viperidae

23.

24.

25.

\section{Family: Agamidae}

1.

2 .

3.

4.

5.

6.

\section{Family: Scincidae}

7.

8.

9.

10.

Family: Varanidae

11.

12.
* Cylindrophis maculatus (Daudin, - Sri Lanka Pipe Snake 1803)

Hypnale hypnale (Merrem, 1820) - Hump-nosed viper

* Trimeresurus trigonocephalaus - Sri Lanka green pit viper

(Sonnini \& Latreille, 1801)

Daboia russelii (Shaw \& Nodder, - Russell's viper 1797)

\section{Order: SAURIA}

Calotes calotes (Linnaeus, 1758) - Green garden lizard

Calotes versicolor (Daudin, 1802) - Common garden lizard

*Calotes liolepis Boulenger, 1885 - Whistling lizard

*Ceratophora aspera Günther, 1864 - Rough-horn lizard

* Otocryptis wiegmanni Wagler, - Sri Lanka kangaroo lizard 1830

*Lyriocephalus scutatus (Linnaeus, - Hump nose lizard 1758)

Mabuya carinata lanka Deraniya- - Rat snake skink gala, 1953

* Nessia burtonii Gray, 1839 - Three-toe snake skink

* Lankascincus fallax (Peters, 1860) - Common Lanka skink

*Lankascincus gansi (Greer, 1991) - Gans's lanka skink

Varanus bengalensis (Daudin, - Land monitor 1802)

Varanus salvator (Laurenti, 1768) - Water monitor 


\section{Family: Gekkonidae}

13.

14.

15.

16.
* Cnemaspis podihuna Deraniya- - Dwarf day Gecko gala, 1953

Hemidactylus frenatus Dumeril \& - Asian House Gecko Bibron, 1836

Hemidactylus brooki Gray, 1845

- Brooke's House Gecko / Spotted House Gecko

Gehyra mutilata (Wiegmann, 1834) - Four-clawed Gecko

Family: Trionychidae

17.

Lissemys punctata (Lacepede, - Flap-shell turtle 1788)

\section{LIST OF BIRD SPECIES OBSERVED AT BKE.}

\section{Order: CICONIIFORMES}

\section{Family: Phalacrocoracidae}

1. Phalacrocorax niger

Family: Ardeidae

2. Bubulcus ibis

3. Egretta garzetta

4. Ardeola grayii

\section{Family: Accipitridae}

5. Ictinaetus malayensis

6. Haliastur indus

7. Spizaetus cirrhatus

8. Spilornis cheela

9. Accipiter badius

\section{Order: GALIFORMES}

Family: Phasianidae

10. * Gallus lafayetii

11. * Galloperdix bicalcarata

\section{Order: GRUIFORMES}

\section{Family: Rallidae}

12. Amaurornis phoenicurus
Little Cormorant

Cattle Egret

Little Egret

Indian Pond Heron

Black Eagle

Brahmini Kite

Changable Hawk Eagle

Crested Serpent Eagle

Shikra

Sri Lanka Junglefowl

Sri Lanka Spurfowl

White Breasted Water Hen

Emerald Dove

Green Imperial Pigeon

Orange Breasted Green

Pigeon

Pompadour Green

Pigeon 
17. Streptopelia chinensis

\section{Order: PSITTACIFORMES}

Family: Psittacidae

18. Psittacula krameri

19. Psittacula cyanocephala

20. * Loriculus beryllinus

\section{Order: CUCULIFORMES}

Family: Cuculidae

21. Eudynamys scolopacea

Family: Centropodidae

22. Centropus sinensis

23. * Centropus chlororhynchus

\section{Order: STRIGIFORMES}

Family: Strigidae

24. Bubo nipalensis

25. * Glaucidium castanonotum

26. Strix leptogrammica

27. Ketupa zeylonensis

Family: Batrachostomidae

28. Batrachostomus monilieger

\section{Order: APODIFORMES}

Family: Apodidae

29. Cypsiurus balasiensis

Family: Hemiprocnidae

30. Hemiprocne coronata

Order: TROGONIFORMES

Family: Trogonidae

31. Harpactes fasciatus

\section{Order: CORACIIFORMES}

Family: Alcedinidae

32. Ceyx erithacus

33. Alcedo atthis

Family Halcyonidae

34. Halcyon smyrnensis

Family: Meropidae

35. Merops philippinus
Spotted Dove

Rose-ringed Parakeet

Plum-headed Parakeet

Sri Lanka Hanging Parakeet

Asian Koel

Greater Coucal

Sri Lanka Green-billed

Coucal

Spot-bellied Eagle Owl

Sri Lanka Chestnutbacked Owlet

Brown Wood Owl

Brown Fish Owl

Frog mouth

Asian Palm Swift

Crested Tree Swift

Malabar Trogon

Oriental Dwarf King-

fisher

Common Kingfisher

White-breasted Kingfisher

Blue-tailed Bee-eater 
36. Merops leschenaultia

Family: Coraciidae

37. Eurystomus orientalis
Chestnutheaded Bee-

eater

Dollarbird

\section{Order: BUCEROTIFORMES}

Family: Bucerotidae

38. * Ocyceros gingalensis

Sri Lanka Grey Hornbill

\section{Order: PICIFORMES}

\section{Family: Megalaimidae}

39. Megalaima zeylanica

40. Megalaima rubricapilla

41. * Megalaima flavifrons

\section{Family: Picidae}

42. Chrysocolaptes lucidus

43. Dendrocopus nanus

44. Dinopium benghalense

\section{Order: PASSERIFORMES}

\section{Family: Pittidae}

45. Pitta brachyura

Family: Passeridae

46. Dendrolanthus indicus

Family: Hirundinidae

47. Hirundo daurica

Family: Corvidae

48. Crovus macrorhynchos

49. Pericrocotus flammeus

50. Pericrocotus cinnamomeus

51. Aegithina tiphia

52. Terpsiphone paradisi

53. Rhipidura aureola

54. Oriolus xanthornus

55. Dicrurus caerulescens

56. Dicrurus paradisius lophorhinus

57. Artamus fuscus

\section{Family: Pycnonotidae}

58. Hypsipetes leucocephalus

59. Pycnonotus melanicterus

60. Pycnonotus cafer

Brown-headed Barbet Crimson-fronted Barbet

Sri Lanka Yellow-fronted Barbet

Greater Flame-back Pigmy Woodpecker

Red-backed Woodpecker

Indian Pitta

Forest Wagtail

Red-rumped Swallow

Large-billed Crow /

Black Crow/ Jungle

Crow

Scarlet Minivet

Small Minivet

Common Iora

Asian Paradise Fly-

catcher

White-browed Fantail

Black-hooded Oriole /

Black headed Oriole

White-bellied Drongo

Crested Drongo / Great racket-tailed Drongo

Ashy Woodswallow

Black Bulbul

Black-crested Bulbul

Red-vented Bulbul 
61. Pycnonotus luteolus

62. Iole indica

Family: Passeridae

63. Lonchura striata

64. Lonchura punctulata

Family: Irenidae

65. Chloropsis cochinchinensis

66. Chloropsis aurifrons

Family: Laniidae

67. Lanius cristatus cristatus

Family: Muscicapidae

68. Muscicapa daurica

69. Hypothymis azurea

70. Copsychus saularis

71. Cyornis tickelliae

Family: Sittidae

72. Sitta frontalis

Family: Silviidae

73. Orthotomus sutorius

74. Phylloscopus trochiloides

75. Phylloscopus magnirostris

76. Turdoides affinis

77. Rhopocichla atriceps

78. * Pellorneum fuscocapillum

79. Pomatorhinus horsfieldii

Family: Paridae

80. Parus major

Family: Nectarinidae

81. *Dicaeum vincens

82. Dicaeum erythrorhynchos

83. Nectarina zeylonica

84. Nectarina lotenia

85. Nectarina asiatica

Family: Zosteropidae

86. Zosterops palpebrosa

Family: Sturnidae

87. Acridotheres tristis

88. Gracula religiosa

89. * Gracula ptilogenys
White-browed Bulbul

Yellow-browed Bulbul

White-rumped Muniya

Scaly-breasted Muniya

Blue-winged Leafbird

Gold-fronted Leafbird

Brown Shrike

Asian Brown Flycatcher

Black-naped Monarch

Oriental Magpie Robin

Tickell's Blue Flycatcher

Velvet-fronted Nuthatch

Common Tailorbird

Greenish Warbler

Large-billed Leaf War-

bler

Yellow-billed Babbler

Dark-fronted Babbler

Sri Lanka Brown capped

babbler

Scimitar Babbler

Great Tit

Sri Lanka Legge's Flowerpecker

Small Flowerpecker

Purple-rumped Sunbird

Long-billed Sunbird /

Loten's Sunbird

Purple Sunbird

Small White-eye / Orien-

tal white eye

Common Myna

Hill Myna

Sri Lanka Myna 
LIST OF MAMMAL SPECIES OBSERVED AT BKE.

\section{CLASS-MAMMALIA Subclass-THERIA Order: CHIROPTERA}

Family: Pteropidae

1. Cynopterus sphinx

2. Pteropus giganteus

Family: Emballonuridae

3. Taphozous melanopogon

Family: Rhinolophidae

4. Rhinolophus rouxii

5. Hipposideros lankadiva

Family: Vespertilionidae

6. Pipistrellus ceylonicus

7. Kirivoula pictus

\section{Order: PRIMATES}

\section{Family: Loridae}

8. * Loris tardigradus tardigradus

Family: Cercopithecidae

9. * Macaca sinica aurifrons

10. * Trachypithecus vetullus vetullus

\section{Order: Rodentia}

Family: Sciuridae

11. Funambulus palmarum

12. * Funambulus layardi

13. Funambulus sublineatus

14. Ratufa macroura melanochra

\section{Family: Muridae}

15. Bandicota indica

16. Mus booduga

17. Mus musculus

18. Rattus rattus

19. Vandeleuria oleracea

Family: Hystricidae

20. Hystrix indica

\section{Order: PHOLIDOTA}

Family: Manidae

21. Manis crassicaudata

Order: LAGOMORPHA

Family: Leporidae

22. Lepus nigricollis
Short-nosed fruit bat

Flying fox

Black-bearded sheath-tailed bat

Rufus horseshoe bat

Great leaf-nosed bat

Kelaart's pipistrel

Painted bat

Sri Lanka Western red slender Loris (En)

Dusky toque macaque (Vu) / Sri Lanka toque monkey

Sri Lanka Purple faced leaf monkey (En)

Palm squirrel

Sri Lanka Flame-striped jungle squirrel

Dusky-striped jungle squirrel

Black and yellow giant squirrel / Giant squirrel

Malabar bandicoot

Field mouse

Indian house mouse

Common house rat

Long-tailed tree mouse

Porcupine

Indian Pangolin

Black-Napped Hare 
Order: CARNIVORA

\section{Family: Viverridae}

23. Viverricula indica

24. Paradoxurus hermaphroditus

25. * Paradoxurus zeylonensis

Family: Herpestidae

26. Herpestes brachyurus

27. Herpestes smithii

Family: Felidae

28. Prionailurus rubiginosa

29. Panthera paradus kotiy

30. Prionailurus viverrinus

Family: Mustelidae

31. Lutra lutra

Family: Canidae

32. Canis aureus

Order: ARTIODACTYLA

\section{Family: Suidae}

33. Sus scrofa

Family: Tragulidae

34. * Moschiola meminna
Ring-tailed civet

Palm cat

Sri Lanka Golden palm civet

Brown mongoose

Black-tipped mongoose

Rusty-Spotted Cat

Leopard

Fishing Cat

Otter

Jackal

Wild boar

Sri Lanka Mouse deer 